\title{
Active volcanism in Colombia and the role of the Servicio Geológico Colombiano
}

\author{
Diego Mauricio Gómez Martínez ${ }^{\star \alpha}$, Cristian Mauricio López Vélez ${ }^{\beta}$, \\ María Luisa Monsalve Bustamante ${ }^{\beta}$, Adriana Agudelo Restrepo $\gamma$, \\ Gloria Patricia Cortés Jiménez ${ }^{\beta}$, Marta Lucía Calvache Velasco ${ }^{\delta}$ \\ ${ }^{\alpha}$ Servicio Geológico Colombiano - Observatorio Vulcanológico y Sismológico de Pasto, Colombia. \\ $\beta$ Servicio Geológico Colombiano - Observatorio Vulcanológico y Sismológico de Manizales, Colombia.

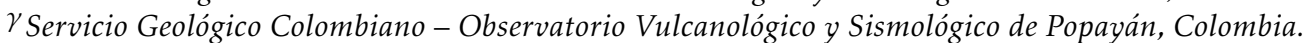 \\ $\delta$ Servicio Geológico Colombiano - Dirección de Geoamenazas, Bogotá, Colombia.
}

\begin{abstract}
The Servicio Geológico Colombiano (SGC) was created in 1916 and has been dedicated to the research and monitoring of active volcanoes in the country since the disaster resulting from the eruption of Nevado del Ruíz Volcano in 1985, where more than 25000 people died due to lahars. Today the SGC has three Volcanological and Seismological Observatories in the cities of Manizales (SGC-OVSM), Popayán (SGC-OVSPop), and Pasto (SGC-OVSP), from where 23 active volcanoes are monitored. The three observatories manage an instrumental network of about 740 stations (permanent and portable) as well as signal repeaters, and cover the disciplines of seismology, geodesy, geochemistry, and potential field, amongst others. Volcanic hazard assessment is also carried out by the SGC, producing hazard maps and reports. These tasks are complemented by programs for promoting geoscience knowledge transfer to the public, developed through different strategies. Although at this time, data derived from volcanic monitoring are not available online, the SGC is analysing this need, for implementation in the near future.
\end{abstract}

Este artículo está disponible en español: https://doi.org/10.30909/vol.04.S1.113139 [PDF ES].

\section{InTRODUCTION}

Colombia is located in the north-western corner of South America and is influenced by the interaction of three tectonic plates: the South American, Pacific and Caribbean plates. This context leads to several geological processes such as the formation of mountain ranges, earthquakes, and volcanism. From a general perspective, Colombia, like the rest of South America, is part of the so-called "Pacific Ring of Fire" which is located around the Pacific Ocean. It corresponds to a zone of interaction between the Pacific, Juan de Fuca, Nazca, and Cocos tectonic plates with the borders of the South American, Caribbean, Eurasian, Philippines, and Australian plates [Monsalve and Mora 2005]. As it is well known, this "belt" has intense seismic and volcanic activity, reflecting a living and dynamic planet.

\subsection{The origin of volcanology in Colombia}

The disaster associated with the eruption of Nevado del Ruíz Volcano on November 13, 1985, which led to the loss of life of about 25,000 Colombians in Tolima and Caldas Departments (northern Colombia), had a great impact not only in the country, but worldwide. It induced important changes that included assigning

\footnotetext{
${ }^{*}$ Corresponding author: dgomez@sgc.gov.co
}

the Servicio Geológico Colombiano (Colombian Geological Survey, SGC) at that time called INGEOMINAS, to be the highest authority in the "study and prevention of all kinds of geological risks" (Decree 3815 of 1985), followed by INGEOMINAS's resolution number 057 of February 5, 1986. Officially, this resolution created the Observatorio Vulcanológico y Sismológico (OVS) of Colombia in Manizales. The Nevado del Ruiz disaster also motivated the design and structuring of a national disaster risk management system in the country, which has improved over the years. In this context, the SGC, created in 1916, has dedicated more than 34 years to the research, and monitoring of active volcanoes in Colombia. Throughout this time, the SGC, through its geohazard, basic geosciences, and laboratory subdivisions, has established and strengthened a group of professionals specialized in different fields of volcanology, including volcanic geology and stratigraphy, volcanic hazard assessment, and volcano monitoring. For monitoring purposes, the SGC uses networks with the most technologically advanced equipment and stations that allow multiparametric observations. This means that a single station can monitor seismicity, ground deformation, gases, and temperature among others, using geophysical, geodetic, and geochemical techniques (Table 1).

Volcanic activity in Colombia occurs in three main regions: South, Central, and North. These regions are 
Table 1: Different techniques and instruments used by the Observatorios Vulcanológicos y Sismológicos of Pasto, Popayan and Manizales of the Servicio Geológico Colombiano (SGC-OVS) for monitoring the active Colombian volcanoes. BB = Broad Band, SP = Short Period. For EDM (Electronic Distance Measurement), BAS $=$ Base, PRIS $=$ PRISMS .

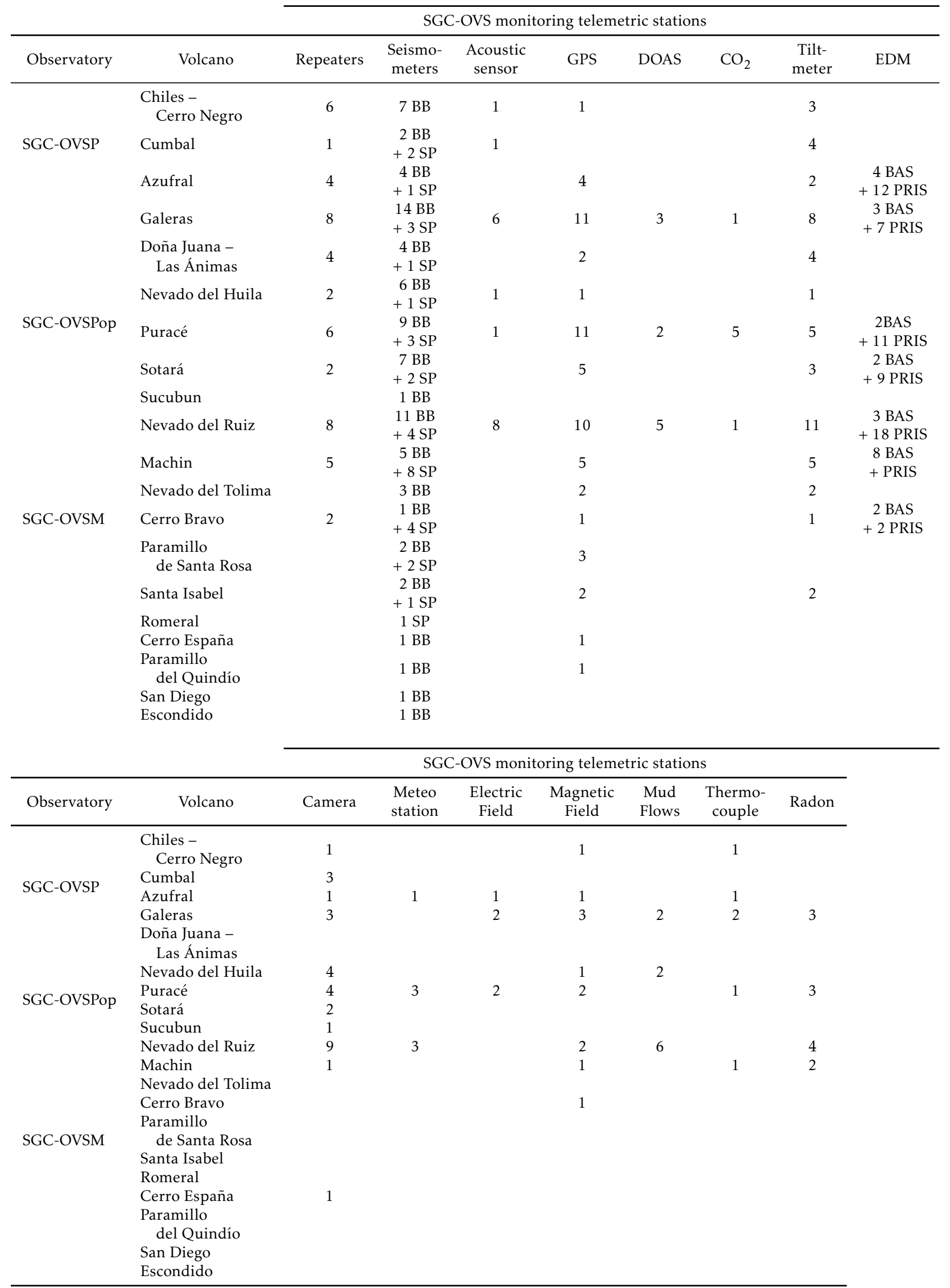


home to 23 active volcanoes (Figure 1), with millions of Colombians living within $100 \mathrm{~km}$ of at least one volcanic center (Table 2). These volcanoes are monitored by the SGC through its three observatories: the Observatorio Vulcanológico y Sismológico de Pasto (SGCOVSP), Popayán (SGC-OVSPop), and Manizales (SGCOVSM).

As mentioned, in 1986 the OVS of Colombia was created, with the purpose of monitoring Nevado del Ruiz volcano and for future studies of other volcanoes in the country. In 1989, the reactivation of Galeras volcano made it necessary to start similar work in Pasto, culminating in the creation of a permanent volcanological observatory in this city. In 1993, based on the experiences acquired while monitoring Nevado del Ruiz and Galeras volcanoes, a plan was made to monitor quiescent Colombian volcanoes to allow detection of advanced signs of changes in their activity. That is how the OVS was created in the city of Popayán, in the absence of a volcanic crisis. Nevertheless, volcano monitoring in this region started at the end of 1986 with the temporary installation of a seismograph near the sector known as Verdum, on Nevado del Huila volcano [Méndez 1989].

\subsection{The active volcanoes of the national territory}

Although all Colombian volcanoes have their own characteristics, conditions, relevance, and challenges in risk management, due to their history and/or potential for future danger [Espinosa 2011], the following aspects should be highlighted. In the northern part of Colombia, Nevado del Ruíz volcano is actively monitored to mitigate the impact of lahars (with estimated volumes between 50 and 100 million $\mathrm{m}^{3}$ ) and the secondary processes they can trigger [Pierson et al. 1990]. Nevado del Ruíz entered a new phase of unrest in 2010, signalled by howing seismicity, deformation, gas and ash emissions, and the growth of a lava dome in the Arenas crater, first observed in August 2015. Cerro Machín volcano, which has the eruptive potential to affect the most populated area of the country, is considered to be one of the most explosive and dangerous volcanoes in Colombia because it has produced devastating explosive eruptions in its past and will likely do so again. Pyroclastic flow deposits and lahar deposits have been found up to $40 \mathrm{~km}$ and $109 \mathrm{~km}$ distance from the volcano, along the Coello and Magdalena rivers, respectively. The most recent eruption of Cerro Machín volcano was recorded approximately 800 years ago [INGEOMINAS 2003; Cortés Jímenez et al. 2006; Gómez Tapias et al. 2016; Piedrahita et al. 2018].

In the central region of Colombia, two volcanoes are highlighted: Puracé, because it is considered very active, with a long record of eruptions in historical times [Monsalve et al. 2014], and Nevado del Huila, because it represents an example of successful risk management involving indigenous communities and institu- tions. On June 6, 1994, a tectonic earthquake of magnitude 6.4 occurred, $10 \mathrm{~km} \mathrm{SW}$ of the rim of Nevado del Huila, generating about 3000 landslides that subsequently caused avalanches along the Páez and Símbola rivers and left about 1100 people dead. Subsequently, the reactivated volcano caused two phreatic events between 2007 and 2008, a phreatomagmatic eruption in 2008 , and the emplacement of a lava dome (with extrusion pulses in 2009 and 2010). This activity generated lahars that flowed down the Páez and Símbola rivers, surficial changes on the volcanic edifice (appearance of cracks and a crater), and loss in the ice cap [INGEOMINAS 2008; Monsalve et al. 2011; Pulgarín et al. 2015]. In 2008, the volcano generated an immense lahar, considered one of the largest historical lahars in the world (estimated at 400 million $\mathrm{m}^{3}$ ). Owing to rapid and efficient coordination, and communication and interaction between institutions and communities, only 10 fatalities occurred and these were a direct result of a failure to follow evacuation orders. This volcanic crisis was managed by the SGC-OVSPop [Monsalve et al. 2011; Pulgarín et al. 2015].

In the southern region of Colombia, Galeras, Azufral, Chiles, and Cerro Negro volcanoes stand out. Galeras is considered, at least in historical times, as one of the most active volcanoes in Colombia, with the potential to affect seven municipalities with about 500,000 inhabitants and municipal headquarters located at distances of less than $12 \mathrm{~km}$ from its active cone. During its most recent period of activity (1989-2010), at least 22 explosive eruptions were recorded [Servicio Geológico Colombiano 2015]. Azufral volcano, located about $12 \mathrm{~km}$ west of Túquerres city, is the only active volcano in Colombia that has a green crater lake. It is considered, together with Cerro Machín volcano, as one of the most dangerous volcanoes in the country, with a record of eruptive processes between approximately 17800 years and 780 years before present [Calvache et al. 2003]. Chiles and Cerro Negro are two active volcanoes that are shared territorially with Ecuador. Although there is some evidence of fumarolic activity, there are no records of eruptions in historical times (last 500 years). Since the end of 2013, a significant increase in earthquake activity has been recorded in the area near these volcanoes, mainly related to fracture of crustal material; as of September 2020, there have been about 780000 earthquakes (VT type), with several events with maximum local magnitudes between 3.5 and 5.6 clearly felt in the region. This situation led to the signing of a ten-year framework cooperation agreement in 2014 between the Director of the Servicio Geológico Colombiano (SGC) and the Rector of the Escuela Politécnica Nacional (EPN), of which the Instituto Geofísico (IG-EPN) is a part. This agreement covers various activities of common interest to the two institutions, including investigation, monitoring, and evaluation of the volcanic hazards. This agreement has facilitated joint monitoring activities at these active vol- 
Table 2: The cities and population exposed to volcanic hazards at relevant active Colombian volcanoes. The population information is based on the 2018 census, conducted by the Departamento Administrativo Nacional de Estadísticas (DANE) and available via the link https://www.dane.gov.co/index.php/estadisticas-por-tema/ demografia-y-poblacion/censo-nacional-de-poblacion-y-vivenda-2018.

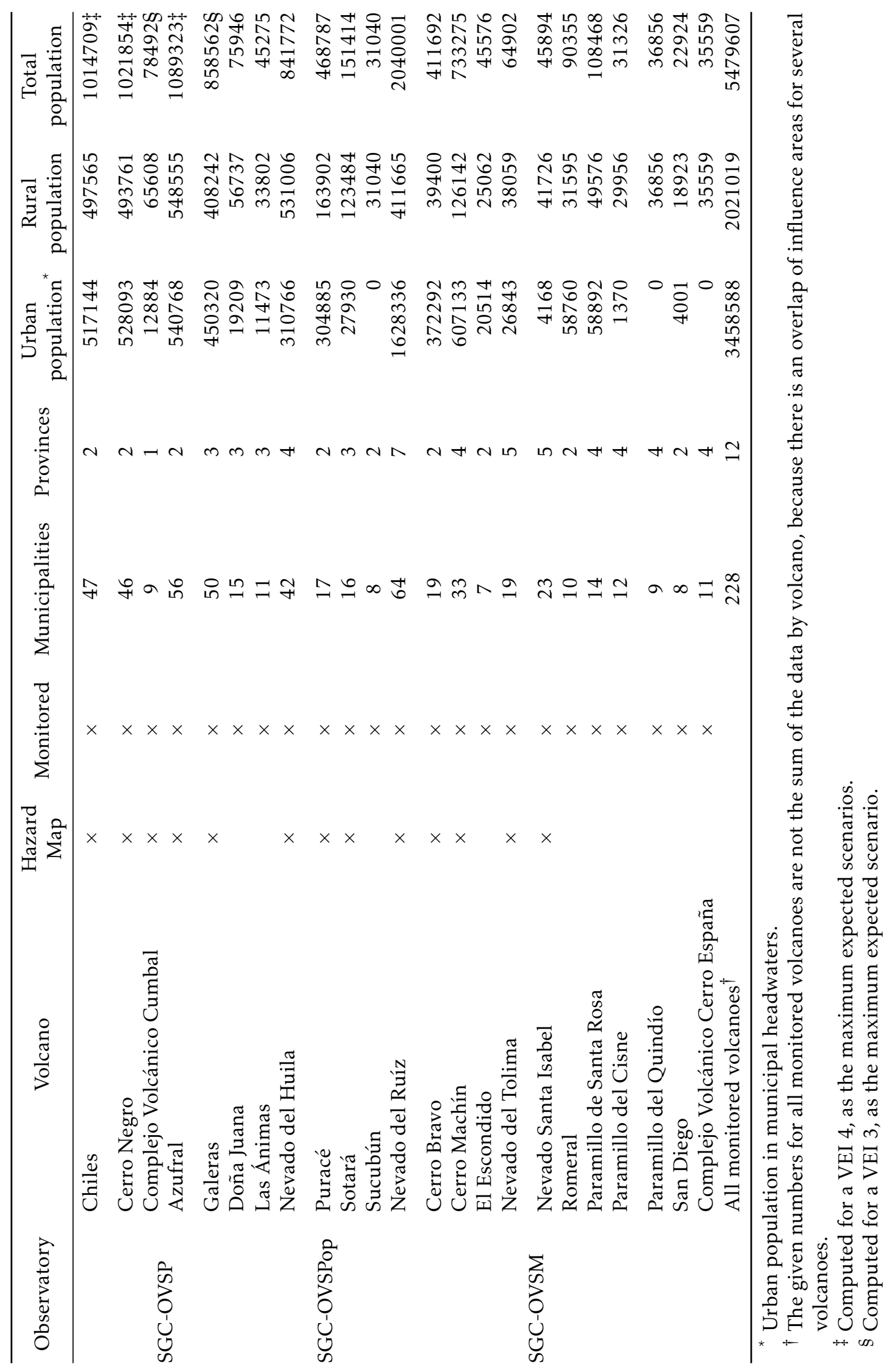




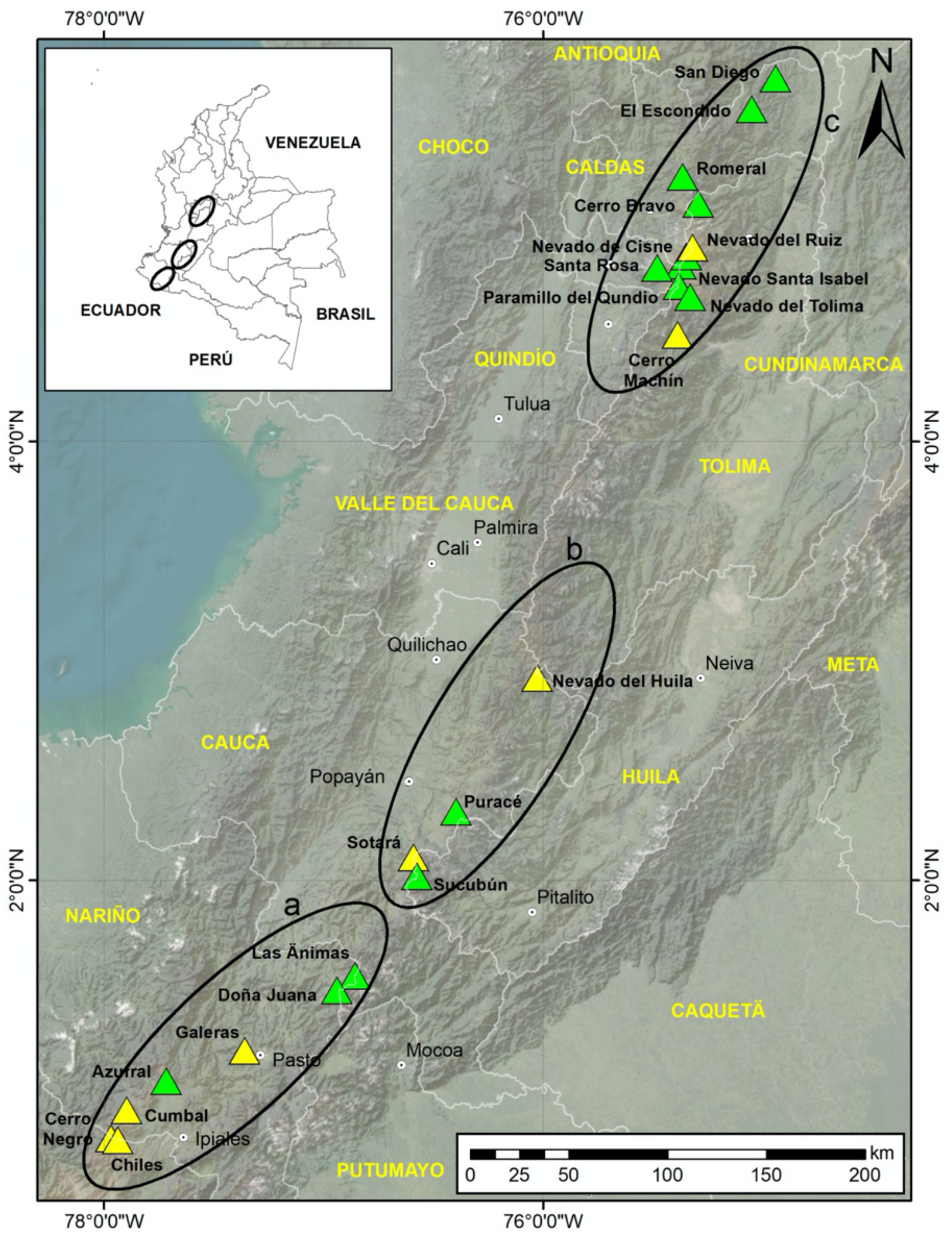

Figure 1: The active volcanoes of the Colombian territory are divided into three geographic segments to the South (a), Center (b), and North (c), and are monitored by the Observatorio Vulcanológio y Sismológico of Pasto (SGCOVSP), Popayan (SGC-OVSPop), and Manizales (SGC-OVSM), respectively. Color coded triangles give information about the current volcanic activity levels: yellow means activity level III, while, green means activity level IV. The main Provinces are noted in black ellipses and the main cities are also shown with a small white dot. 
canoes along the border.

There are about 5.5 million people exposed to volcanic hazards of some of the main active Colombian volcanoes (Table 2). For this approximation, the information from hazard maps, in terms of the area that can be covered by ash fall deposits, is compared with territorial limits and official census data. The output information can be sorted as a function of rural, urban, or total areas exposed to high, medium, or low hazard zones.

\section{HOW DO WE MONITOR THESE VOLCANOES?}

Currently, the SGC-OVS maintains a multi-parameter instrumental network used for monitoring and research, which integrates disciplines such as geophysics, geochemistry, geodesy, and volcanology (Table 1). These approaches employ state-of-the-art technologies that allow the acquisition of data (e.g. seismic, GNSS, tiltmeter, gases, cameras, etc.) used to diagnose and assign the level of activity to each monitored volcanic structure. The observatories also engage in eruption forecasting and providing information based on knowledge of active volcanoes and their associated hazards, which decision makers can use for land-use planning. Today, 23 potentially active volcanoes are monitored, and as of December 2019, the monitoring network includes seismology, geodesy, geochemistry, potentialfield (magnetic and electric methods), web cameras, with a total of 741 stations in the country (Table 1) of which 397 are permanent (transmitting data by telemetry) and 344 are non-permanent (for these, data are collected during fieldwork). Permanent or telemetric stations transmit data at different sampling rates (varying from 4 to $100 \mathrm{~Hz}$ ) in real time to the observatories, where data are collected, processed, and stored in high capacity servers. The SGC-OVS operates continuously, with specialized technical and professional personnel (Table 3) working in shifts 24 hours a day, 365 days a year, and with the support of undergraduate students who come from geology, basic sciences, geography, chemistry, and engineering departments of regional universities in Manizales, Popayán, and Pasto.

With the expansion of the monitoring networks, the need to maintain their operation also increases. Thus, it is important to rely on highly qualified teams and financial resources to keep $100 \%$ of the elements in the monitoring network operational.

To acquire and process the volcanic monitoring information, the SGC-OVS uses different tools depending on the monitoring area. The acquisition of seismic data is carried out by specific software depending on the types of digitizers installed, and include Scream ${ }^{*}$, Slink2 ew ${ }^{\dagger}$, and Reftek ${ }^{\ddagger}$. To concentrate, dis-

\footnotetext{
${ }^{*}$ https://www.guralp.com/sw/scream

${ }^{\dagger}$ http://www . earthwormcentral.org/documentation4/ovr/ slink2ew_ovr.html

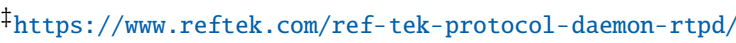

tribute, and store information acquired in standard formats, we use Earthworm ${ }^{\S}$ software and seiscomp3 ${ }^{\mathbb{I}}$. Primary seismic data processing, including classification of earthquakes, reading of basic parameters, location, and calculation of local magnitude, is carried out using Provig and Lakiy tools, which were developed by our observatories' staff. The Provig application is used to perform manual data processing and Lakiy (in development) is used to perform automatic data processing in order to obtain processed information in nearly real time. Secondary processing is carried out through scripts developed by the technical staff, using both free and commercial software.

Ground deformation-detecting instruments including Global Positioning System (GPS) and electronic tiltmeters are used to monitor surface deformation. Data acquisition of GPS data is done using the Trimble $4 \mathrm{D}^{\|}$control software and GAMIT ${ }^{* *}$ is used for processing. Electronic tiltmeter data are acquired by means of the Advanced TCP IP Data Logger Software ${ }^{\dagger \dagger}$, and then processed using scripts developed by technical personnel dedicated to deformation processes and visualized using the GEODATA application also developed by our staff.

For geochemical monitoring, we use telemetered instruments to measure $\mathrm{SO}_{2}, \mathrm{CO}_{2}$, radon, and temperature. The measurement of $\mathrm{SO}_{2}$ data is carried out using NOVAC ScanDOAS and MobilDOAS instruments [Garzón et al. 2008; 2013]. For $\mathrm{CO}_{2}$, radon, and thermocouple data acquisition, we use the Advanced TCP IP data logger software and another software program designed by our engineers.

Electromagnetic (EM) monitoring is performed using a network of electric and magnetic field sensors. The electric field is measured in the NS and EW directions. The NS direction runs more or less perpendicular to the topographic contour lines and in direction of the inclination of the cone walls at the point of the EM station, while the EW direction runs more or less parallel to the contour lines. The electrodes used are non-polarizable copper-sulphate electrodes. The electrode separation for each component is $100 \mathrm{~m}$. In addition to the electric field, the three components of the magnetic field are recorded, (NS, EW, and vertical), using a Fluxgate FL3100 magnetometer (SENSYS type), with a sensitivity of 0.1 nanoT. The data of the two electric channels and the three magnetic channels are digitized with a 24 bit Guralp digitizer with 50 samples per second for each channel and are automatically transmitted to the observatory in charge. Data are acquired through Scream and Reftek software and the stored data are processed by scripts written by observatory staff.

\footnotetext{
$\S_{\text {http: //wWw .isti.com/products/eq-monitoring-seismic-software/ }}$ earthworm/

$\mathbb{I}_{\text {https: //wWw. seiscomp3.org/doc/jakarta/current/index.html }}$

$\|_{\text {https://www.trimble.com/Monitoring-Solutions/ }}$ Trimble-4D-Control . aspx

${ }^{* *}$ http: //geoweb.mit.edu/gg/

${ }^{+\dagger}$ https://wWw .aggsoft. com/tcpip-data-logger.htm
} 
Table 3: Staff distribution by thematic areas, for the three Observatorios Vulcanológicos y Sismológicos (OVS) in charge of research and monitoring of the active Colombian volcanoes.

\begin{tabular}{|c|c|c|c|c|c|c|c|}
\hline Institution & Coordinator & Seismology & Deformation & Geochemistry & Geology & Potential Fields & \\
\hline SGC-OVSP & 1 & 3 & 2 & 1 & 1 & 2 & \\
\hline SGC-OVSPop & 1 & 8 & 1 & 1 & 3 & 0 & \\
\hline SGC-OVSM & 1 & 5 & 2 & 3 & 5 & 1 & \\
\hline Institution & Electronics & Systems & GIS & Hazard modelling & Field support & Administrative support & Total \\
\hline SGC-OVSP & 3 & 2 & 1 & 2 & 3 & 5 & 26 \\
\hline SGC-OVSPop & 3 & 3 & 0 & 1 & 4 & 3 & 27 \\
\hline SGC-OVSM & 2 & 3 & & 2 & 8 & 5 & 37 \\
\hline
\end{tabular}

In addition, we have software developed by the SGCOVS that makes it easier for the technicians in charge of volcanic surveillance to consult, plot, and analyze all of the information acquired. Currently, these programs are only available for the SGC-OVS users. Seismic data processing is performed online, manually and automatically. Due to their nature and acquisition rates, deformation, geochemical, and electromagnetic data are processed in batches at different intervals, which vary from hours to days.

In terms of storage systems, in the SGC-OVS, volcanic monitoring data related to all the areas of surveillance are stored continuously by using different technological structures. Current information is accessed immediately and regularly on the same equipment associated with the acquisition system. At present, there is an approximate daily average of 25 GB of data, distributed in binary files and structured in database engines, which are stored on high-capacity servers, with periodic backup locally and remotely at the Central SGC headquarters. Presently, data related to volcanic monitoring can be used by the OVS staff, and is not fully available to external users, especially data collected and processed with still under-development in house tools. The issue of public data availability is being analyzed within the SGC and we envision that in the future much of the primary monitoring information may be available online.

\section{VOLCANO HAZARD MANAGEMENT}

In Colombia, according to the national law 1523 of 2012, hazard is defined as "the latent danger that a physical event of natural origin [in this case, volcanic] [...] occurs with sufficient severity to cause loss of life, injury or other impacts on health, as well as damage and loss to property, infrastructure, livelihoods, service provision, and environmental resources" [Congreso de la República 2012].

The SGC has established a methodological procedure (Figure 2) to assess volcanic hazard in Colombia [Monsalve 2000]. It begins with detailed research and geological characterization of the volcano under study, which includes field and laboratory work, and culminates with a geological map of the volcano. These field activities include identification, characterization, mapping, stratigraphic correlation, and sampling of the volcanic deposits. The samples are sent to the laboratory for granulometric analysis, component classifications, petrography, geochemistry, isotopic geochemistry, and dating. The process continues with analysis of historical eruptive activity if that information is available. Finally, this information-combined with results of modeling and computational simulation of possible volcanic phenomena-leads to a zonation map of volcanic hazards [Cepeda 2009]. It is important to mention that there is no established international standard for the graphic representation of volcanic hazard maps [Monsalve 2000; Calder et al. 2015]. In Colombia, hazard map formats are the result of technical discussions of a specialized SGC working group. The goal is that these maps are understandable to the authorities and the community in general, based on geological knowledge and internationally used methodologies and analytical tools.

Hazard maps specify areas that may be affected by different volcanic phenomena, based on computational simulations of past volcanic phenomena. For the numerical simulation of the possible volcanic phenomena, different types of tools are used, such as: TITAN2D [Patra et al. 2005], FLOW2D [Sheridan and Macías 1992] and FLOW3D [Kover 1995; Sheridan and Kover 1996], LAHARZ [Schilling 1998; 2014], TEPHRA2 [Bonadonna et al. 2005], ASH-3D [Schwaiger et al. 2012], EJECT! [Mastin 2001], LAVA PL and LAVA C [Connor et al. 2012; Richardson and Connor 2014]. For the analyses, it is assumed that possible future eruptions may be similar to those of the eruptive history of the volcano, and that the center of eruptive activity will be the current crater or craters. Generally, the SGC volcanic hazard maps have three zones designated as high, medium, and low hazard. The boundaries between the different zones are transitional, represented with dashed lines and in no way imply absolute limits. This zoning is based on the potential damage caused by volcanic phenomena, considering the possibility that a given area may be affected by one or more of these phenomena simultaneously. Phenomena such as pyroclastic density currents, lahars, and lava flows, which represent a high severity for impacts, are classified as a high volcanic hazard. Py- 

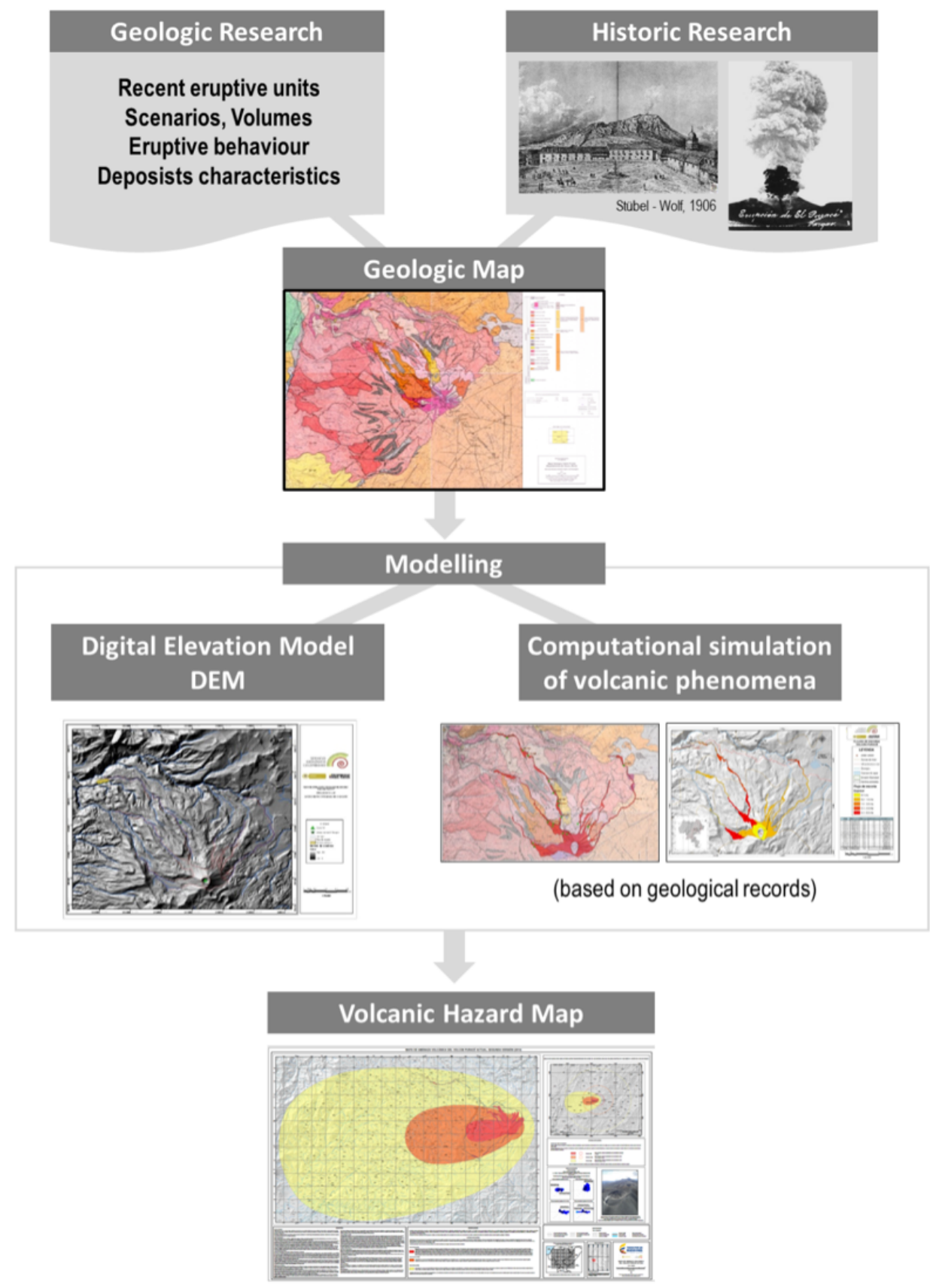

Puracé volcanoi Hazard Map (SGC, 2014)

Figure 2: Graphic description of the methodology used by the SGC for the evaluation of volcanic hazard in Colombia [Modified from Servicio Geológico Colombiano 2015].

roclastic falls and shock waves can be classified from high to low hazard, depending on the distance to the crater and its physical parameters such as thickness, size, pressure, and dispersion direction.

As mentioned before, the seismic crises at ChilesCerro Negro volcanoes at the end of 2013, in addition to the joint monitoring process, led to SGC and the IGEPN to work together in order to produce volcanic hazard maps for Chiles and Cerro Negro Volcanoes under the framework cooperation agreement signed in 2014. This was done through scientific meetings that took place both in Quito (Ecuador) and Ipiales and Pasto (Colombia). Afterwards, those maps were adapted by SGC and IGEPN to the respective national standards, symbolism, terms, and socialized with its respective authorities and communities in 2014.

The official volcanic hazard maps are published on the institutional website ${ }^{*}$. As an example, for Galeras volcano, the map as a PDF file and its explanatory doc-

\footnotetext{
${ }^{*}$ https://wWw.sgc.gov.co/volcanes
} 
ument can be downloaded ${ }^{*}$. Users can also request the information through the institutional search engine $^{\dagger}$ or can make specific requests with more technical details to the following institutional email address: client@sgc.gov.co.

\section{INFORMATION DISSEMINATION AND OUT- REACH}

The Sistema Nacional para la Gestión del Riesgo de Desastres (SNGRD) in Colombia were updated through the law 1523 of 2012, which is based on three tenets, which are all interrelated although they can be carried out independently: risk knowledge, risk reduction, and disaster management. Fundamentally, this law considers that disaster risk management "is a social process for the formulation, execution, monitoring and evaluation of policies, strategies, plans, programs, regulations, instruments, measures and permanent actions for knowledge and risk reduction and for disaster management, with the explicit purpose of contributing to people's safety, well-being, quality of life, and sustainable development". The law also states that "management of risk is the responsibility of all the authorities and the inhabitants of the Colombian territory".

In this context and within the framework of the SNGRD, the SGC is responsible for advising and producing research, studies, documents, reports, maps, etc., focused on improving knowledge of geological process and hazards (e.g. seismic, volcanic, and mass movements, amongst others). The goal for these products, is to be understood and used as input for risk assessment, decision making, land-use planning, andprincipally-to contribute to disaster risk reduction and mitigation. For the case of volcanic activity, the SGC provides two fundamental tools to authorities, institutions, decision makers, and communities: the volcanic hazard maps described above, and volcanic activity levels, which are the result of the integration and evaluation of all the multi-parametric, continuous monitoring information collected by the SGC-OVS for the active volcanoes in the country. Volcanic activity levels (Figure 3) were proposed by the SGC in 2004 to the disaster risk management authorities of Nariño Department following the eruptions of Galeras Volcano, but have now been adopted for all active volcanoes in Colombia. Activity levels have 4 stages ranging from level IV or green, which means active volcano with stable behavior, to level I or red, which corresponds to impending or ongoing eruption. As mentioned, the level of activity is established with the evaluation of the different monitoring parameters for a given instrumented volcano and the evaluation made by the group of experts in the Volcanological Observatories. The descrip-

\footnotetext{
${ }^{*}$ https://www2.sgc.gov.co/sgc/volcanes/VolcanGaleras/ Paginas/Mapa-de-amenaza.aspx

${ }^{\dagger}$ https://miig.sgc.gov.co/Paginas/advanced.aspx
}

tion and details of the meaning of these Volcano Activity Levels are explained online ${ }^{\ddagger}$. Based on both volcanic hazard maps and activity levels, local risk management authorities residing near active volcanoes in Colombia consult with their communities and then design and coordinate contingency plans and response strategies. These include alert levels and within them, the actions that communities must follow during volcanic unrest, such as evacuation orders for those who live in areas where phenomena such as pyroclastic density currents may occur.

Over 34 years of uninterrupted volcanic surveillance and research, a significant number of crises have been faced, which, based on a strengthened institutionalism and reliance on state-of-the-art instrumental networks, have had successful responses. Benefits for the country include not only saving human lives, but also protecting cultural and economic resources. Among these crises are those of Galeras, Chiles, Cerro Negro, Cerro Machín, Puracé, Sotará, Nevado del Huila, and Nevado del Ruiz volcanoes, some of which are ongoing.

\subsection{Strategies for Apropiación Social del Conocimiento Geocientífico on volcanism}

All SGC personnel are convinced that outreach work must be transmitted in the best way to our users. Knowledge provided must be understood and appropriately used. The importance of traditional knowledge and beliefs of communities and their incorporation in risk analysis is also recognized. All of these strategies are used in the framework of the strategies for Apropiación Social del Conocimiento Geocientífico (ASCG) [Narváez Zuñiga et al. 2015; Cortés Jímenez 2016]. In the context of volcanic risk management, the SGC and its observatories have been implementing a series of activities or strategies that, due to their complexity and detail, are briefly presented in this document, highlighting the following:

- Social networks, which are used for mass communication, including the SGC website (urlwww.sgc.gov.co), Facebook (@sgcolombiano), Twitter (@sgcol) and YouTube (ServicioGeologicoC).

- National Biennials of Children and Young People who live in areas of volcanic risk $(2011,2013$, 2015, 2018, and 2020), which is an important activity aimed at education and communication. In February 2020, the fifth biennial was held in the area of volcanic risk ("influence area") of Nevado del Ruíz volcano and in the Omaira Sánchez memorial park [Gómez 2015; Cortés Jímenez and Castaño 2016; López et al. 2018].

- Open observatories, itinerant or mobile observatories, guided tours, agreements with national or in-

\footnotetext{
$\ddagger_{\text {https: //www2 .sgc.gov.co/Paginas/ }}$ niveles-actividad-volcanes.aspx
} 


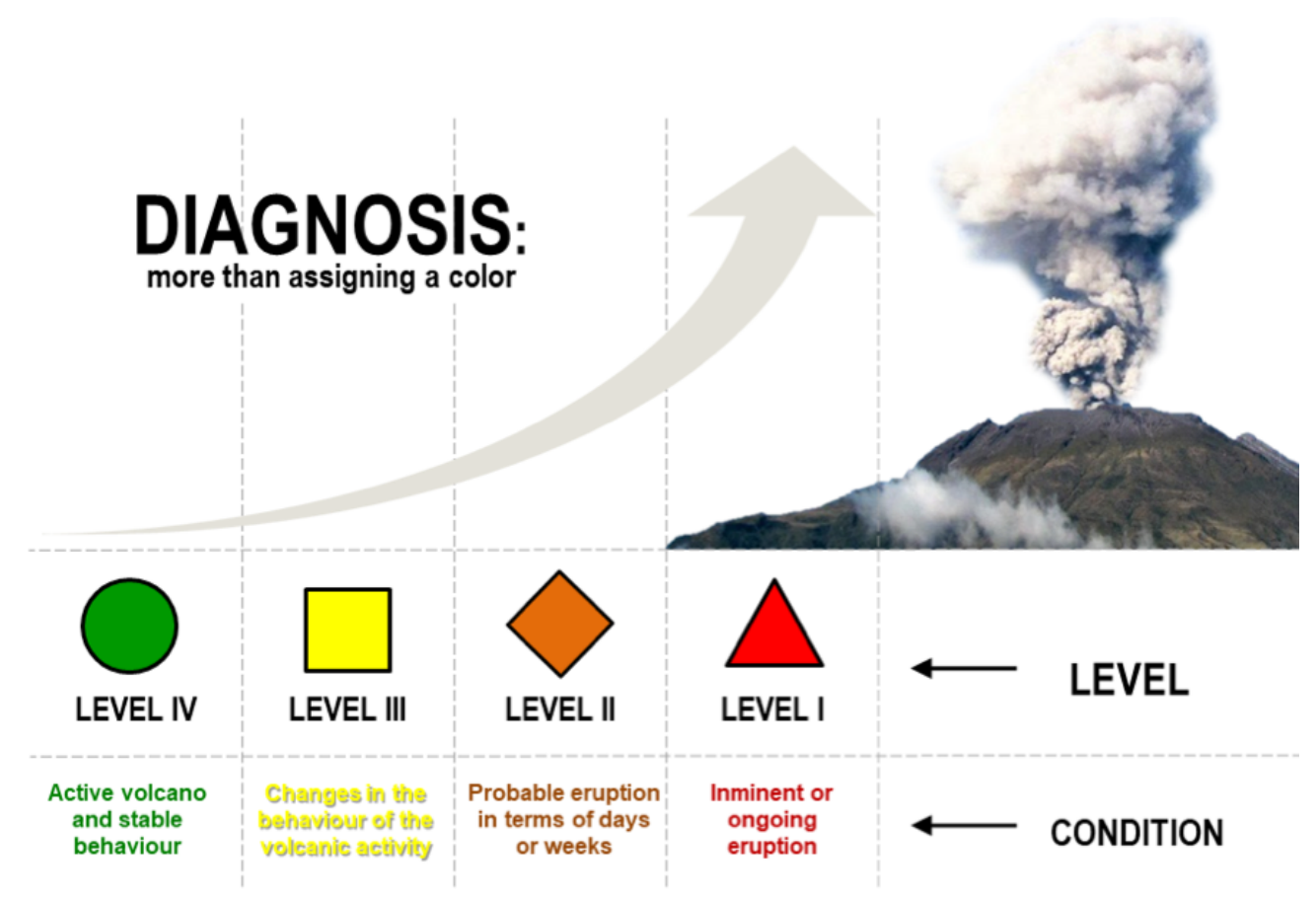

Figure 3: The volcanic activity levels established by the SGC for Colombian active volcanoes that have instrumental monitoring systems.

ternational institutions, which are strategic activities aimed at strengthening the institutional position in the territories.

- Numerous cooperative programs with communities including workshops, pedagogical walks to the volcanoes, guides, specific projects with educational institutions, amongst others [Agudelo et al. 2012; Driedger et al. 2020].

Recent disasters such as the one in Guatemala after the eruption of Fuego volcano on June 3, 2018, encourage all involved in disaster risk management, including the authorities and communities, to re-think the importance of understanding volcanic hazards and their related uncertainties. Disasters also challenge us to strengthen knowledge and risk reduction, in order to have communities and institutions much better prepared to confront this type of natural phenomena. This is in accordance with a fundamental premise: "to understand the risk, is to reduce it", stated as part of a project developed in Galeras by the European Commission Humanitarian Aid department's Disaster Preparedness Programme [DIPECHO 2007]. The idea behind this sentence is to learn from such a tragedy, the importance of knowing how to make better decisions and understand that although volcanoes will always generate small or large eruptions, eruptions should not always cause disasters. The potential for disaster depends on our knowledge of the phenomena and in our actions aimed at mitigating their impact. If all communities and institutions work together continuously on risk management, it would aid in never again having disasters as unfortunate as those that Guatemala has recently experienced or those that Colombia experienced in 1985 after the eruption of Nevado del Ruíz Volcano.

\section{Needs, Challenges, AND future Perspec- TIVES}

Although Colombia-since its formal inception in studying, researching, and monitoring volcanic activity - has been used as a regional role-model, there are a significant number of needs related to the growth achieved in 34 years of uninterrupted study, in the increased number of active volcanoes monitored (from 1 in 1985 to 23 in 2020), and the corresponding monitoring networks, acquisition systems, and so on. Some of these needs are: to maintain continued operation of the extensive volcanic monitoring and research network; to strengthen and complement the current monitoring networks; to implement instrumentation on new active volcanic structures, mainly where there is a community under some degree of risk; to keep scientific personnel trained in order to work continuously to understand processes driving volcanic activity, with a view to being recognized not only regionally, but internationally. Further, continued outreach and collaboration with local communities, including indigenous communities, remains an important priority. These efforts are both a challenge and a memorial to the thousands of people who have died due to volcanic activity, not only in Colombia, but worldwide, with the final goal of reducing disasters related to volcanic 
activity, and contributing to generating more resilient communities.

\section{ACKNOWLeDgements}

The authors appreciated the relevant contribution of Eveling Espinoza and Pablo Forte, as well as two anonymous reviewers, for improving this paper. Many thanks to all the members of the SGC-OVS for their permanent work in the investigation and monitoring of the Colombian active volcanoes and the contributions made to this article. Special thanks to Carlos Muñoz (SGC-OVSP) for his support in ArcGIS analysis, and Rafael Cárdenas (SGC-OVSP) and Andrés Narváez (SGC-OVSPop) for their help improving the figures.

\section{Author contributions}

For the fulfillment of its missionary activity, the SGC has in its structure seven Technical Areas, one of which is GeoHazards, from where research and monitoring of geological hazards in the country are conducted (earthquakes, volcanoes, and mass movements). Dr. Marta Calvache is the Director of GeoHazards, in charge of the guidelines and managing the necessary resources so that the mission can be carried out, both technically and administratively. López $\mathrm{C}$. M, is the person in charge of the direction of the research and monitoring project of the active volcanoes in the country, managing the human and economic resources that are assigned annually. Monsalve, Agudelo, and Gómez, are the scientists in charge of the coordination of the three OVS in the country, respectively the SGC-OVSM, SGCOVSPop, and SGC-OVSP, from where the monitoring of the different active volcanoes located in the northern, central, and southern segments in Colombia occurs. Cortés, G.P, was in charge of the direction of the research and monitoring project of the active volcanoes of the country between 2004 and 2011, and was the scientist in charge of SGC-OVSM from 2010 to 2018. In this context, this article shows the result of an entire team that has been working on the research and monitoring of active Colombian volcanoes for more than 34 years.

\section{Data aVailability}

Currently, data related to volcanic monitoring is not fully available to the public, especially those collected and processed with under-development tools. Access to seismic data can be requested through email or written petition. Access is subject to data use within a research project. This issue is being analyzed within the SGC and it is believed that in the future, much of the primary monitoring information may be available online.

Other types of documents, such as hazards maps, geologic maps, reports, bulletins, photos, and videos can be obtained online through our website (https://www.sgc.gov.co/volcanes/index.html, or https://www.sgc.gov.co/Publicaciones/Paginas/ informes-tecnicos.aspx, or https://www.sgc.gov.co/ Noticias/Paginas/Boletines-extraordinarios.aspx, or https://www.sgc.gov.co/Noticias/Paginas/ Boletines-mensuales.aspx), or by consulting the institutional search engine ("Geoportal"), by navigating to the following link and following the instructions there: https://www.sgc.gov.co/sgc/mapas/Paginas/ geoportal.aspx.

\section{COPYRIGHT NOTICE}

(c) The Author(s) 2021. This article is distributed under the terms of the Creative Commons Attribution 4.0 International License, which permits unrestricted use, distribution, and reproduction in any medium, provided you give appropriate credit to the original author(s) and the source, provide a link to the Creative Commons license, and indicate if changes were made.

\section{REFERENCES}

Agudelo, A., A. Narváez, and Y. Ramírez (2012). "Experiencias en la construcción de la gestión del riesgo en el cañón del río Páez. Red de Desastres Hidrometeorológicos y Climáticos (REDESClim)." Memorias II Congreso Regional SRA-LA. Capitulo Latinoamérica, Bogotá, Colombia, 9-12 April. Ed. by F. Muñoz. Bogotá, Colombia: Sociedad para el Análisis de Riesgos, pp. 210-215.

Bonadonna, C., C. B. Connor, B. F. Houghton, L. Connor, M. Byrne, A. Laing, and T. K. Hincks (2005). "Probabilistic modeling of tephra dispersal: Hazard assessment of a multiphase rhyolitic eruption at Tarawera, New Zealand". Journal of Geophysical Research 110 (B3). DoI: 10.1029/2003jb002896.

Calder, E., K. Wagner, and S. Ogburn (2015). "Volcanic hazard maps". Global Volcanic Hazards and Risk. Ed. by S. C. Loughlin, S. Sparks, S. K. Brown, S. F. Jenkins, and C. Vye-Brown. Cambridge University Press, pp. 335-342. Dor: 10.1017/cbo9781316276273.022.

Calvache, M. L., M. P. Torres, G. P. Cortés Jímenez, and M. L. Monsalve (2003). "Geología y estratigrafía del volcán Azufral, Colombia". Ed. by INGEOMINAS. Bogotá, Colombia: INGEOMINAS, p. 52.

Cepeda, H. (2009). Escenarios eruptivos posibles y la gestión de riesgo volcánico. Tech. rep. Manizales, Colombia: Instituto Colombiano de Geología y Minería, p. 9.

Congreso de la República, Departamento Administrativo de la Función Pública (2012). Política Nacional de Gestión del Riesgo de Desastres y se establece el Sistema Nacional de Gestión del Riesgo de Desastres y se dictan otras disposiciones. Bogotá. Ley 1523 de 2012. 
Connor, L. J., C. B. Connor, K. Meliksetian, and I. Savov (2012). "Probabilistic approach to modeling lava flow inundation: a lava flow hazard assessment for a nuclear facility in Armenia". Journal of Applied Volcanology 1 (1). DOI: 10.1186/2191-5040-1-3.

Cortés Jímenez, G. P. (2016). “Apropiación social del conocimiento científico: treinta años de la vulcanología en Colombia, la gestión exitosa del riesgo volcánico el gran reto". Simposio Servicio Geológico Colombiano, 100 años de producción científica al servicio de los colombianos. Ed. by J. Gómez Tapias. Bogotá: Servicio Geológico Colombiano.

Cortés Jímenez, G. P., H. F. Murcia, B. O. Hurtado, H. Cepeda, and A. Núñez (2006). "Comparison of the lahar deposits of the eruption of Nevado del Ruiz volcano on 13th of November 1985 and the prehistoric eruptions of Cerro Machín volcano in the central zone of Colombia". Fourth Conference Cities on Volcanoes-IAVCEI, Quito, Ecuador, January 22-27. Quito, Ecuador.

Cortés Jímenez, G. P. and L. J. Castaño (2016). Informe tercera Bienal Nacional de niños, niñas y jóvenes que viven en zonas de riesgo volcánico. Tech. rep. Servicio Geológico Colombiano.

Disaster Preparedness ECHO (2007). Reducción de la Vulnerabilidad de Comunidades Ubicadas en la Zona de Amenaza Alta frente al Volcán Galeras. Tech. rep. Cruz Roja Colombiana \& Cruz Roja Francesa.

Driedger, C., M. Calvache, G. P. Cortés Jímenez, J. Ewert, J. Montoya, A. Lockhart, R. Allen, D. Banks, S. Beason, H. T. Bocanegra, F. Burkhart, K. Bustad, J. A. Gallego, Z. Gibson, F. R. Giraldo, C. Gutierrez, J. I. Quintero, E. Rodríguez, J. Schelling, and M. Scott (2020). "Leveraging lessons learned to prevent future disasters-insights from the 2013 Colombia-US binational exchange". Journal of Applied Volcanology 9 (1). DOI: $10.1186 /$ s13617-019-0090-8.

Espinosa, A. (2011). Enciclopedia de desastres naturales históricos de Colombia: erupciones históricas de los volcanes colombianos, 1550-2000. Bogotá: Academia Colombiana de Ciencias Exactas, Físicas y Naturales y Universidad del Quindío.

Garzón, G., C. Santacoloma, B. Galle, and E. Solarte (2008). "Estrategias de medición de gases volcánicos en Colombia, utilizando sensores ópticos remotos". Bistua: Revista de la Facultad de Ciencias Básicas 6 (2), pp. 32-40. IssN: 0120-4211.

Garzón, G., B. Silva, A. Narvaez, Z. Chacon, and B. Galle (2013). "Assessment of $\mathrm{SO}_{2}$ emissions from three Colombian active volcanoes". Science Without Borders: Transactions of the International Academy of Science HEE. Ed. by W. Kofler and E. Khalilov. International Academy of Science H\&E, pp. 316-325. ISBN: 978-9952-451-04-7.

Gómez Tapias, J., M. L. Monsalve, N. E. Montes, and L. S. Ortiz (2016). "Excursión de campo Historia geológica de los Andes colombianos en los alrededores de Ibagué". Simposio Servicio Geológico Colom- biano, 100 años de producción científica al servicio de los colombianos. Ed. by J. Gómez Tapias. Bogotá: Servicio Geológico Colombiano.

Gómez, D. (2015). Informe sobre la I y II Bienales Nacionales de Niños, Niñas y Jóvenes que Viven en Zonas de Riesgo Volcánico, desarrolladas en San Juan de Pasto en los años 2011 y 2013. Tech. rep. Servicio Geológico Colombiano.

Instituto Colombiano de Geología y Minería (2003). Memoria explicativa del mapa de amenaza Volcánica del Cerro Machín. Observatorio Vulcanológico y Sismológico de Popayán. Tech. rep. Instituto Colombiano de Geología y Minería.

- (2008). Informe de actividad del volcán Nevado del Huila en noviembre de 2008. Observatorio Vulcanológico y Sismológico de Popayán. Tech. rep. Instituto Colombiano de Geología y Minería.

Kover, T. P. (1995). "Application of a digital terrain model for the modeling of volcanic flows: a tool for volcanic hazard determination". MA thesis. State University of New York at Buffalo, USA.

López, C. M., M. L. Calvache, and G. P. Cortés Jímenez (2018). "The Omaira Sanchez commemorative park: a new approach in the social appropriation of geoscientific knowledge of volcanic areas in Colombia." Millenia of stratification between human life and volcanoes: strategies for coexistence (Cities on Volcanoes 10, Abstracts Volume). Ed. by R. A. Corsaro, M. G. Di Giuseppe, R. Isaia, A. Mormone, and R. Nave. Vol. 1. Cities on Volcanoes. Napoli, Italy: Istituto Nazionale Geofisica e Vulcanologia, p. 1200.

Mastin, L. G. (2001). "A simple calculator of ballistic trajectories for blocks ejected during volcanic eruptions" (US Geological Survey Open-File Report 200145). DoI: 10.3133 /ofr0145.

Méndez, R. (1989). "Catálogo de los volcanes activos de Colombia”. Boletín geológico 30 (3).

Monsalve, H. and H. Mora (2005). "Esquema Geodinámico regional para el Noroccidente de Suramerica (modelo de subducción y desplazamientos relativos)". Boletín de Geología 27 (1), pp. 25-53.

Monsalve, M. L. (2000). Guía para la evaluación de la amenaza volcánica y elaboración de mapas de amenaza volcánica potencial en Colombia. DoI: 10.13140/RG. 2 . 1.3641 .3848 .

Monsalve, M. L., J. J. Galarza, I. Zuluaga, and C. A. Laverde (2014). Mapa de amenaza volcánica del volcán Puracé actual (Cauca-Colombia) segunda versión. Tech. rep. Servicio Geológico Colombiano.

Monsalve, M. L., B. A. Pulgarín, J. Mojica, C. C. Santacoloma, and C. E. Cardona (2011). "Interpretación de la actividad eruptiva del volcán Nevado del Huila (Colombia), 2007-2009: análisis de componentes de materiales emitidos". Boletín de Geología 33 (2), pp. 73-93.

Narváez Zuñiga, A., A. Agudelo, Y. Ramírez, J. Quijano, and 1. Montoya (2015). "Estrategia de divulgación y comunicación para la Gestión del Riesgo con 
comunidades educativas de la Cuenca del Río Páez, área de influencia volcán Nevado del Huila”. XV Congreso Colombiano de Geología Innovar en Sinergia con el Medio Ambiente. Ed. by E. S. C. de Geología. Vol. 1. Bucaramanga, Colombia: Sociedad Colombiana de Geología, pp. 618-622. DoI: 10.13140/RG . 2.1.4731.3126.

Patra, A., A. Bauer, C. Nichita, E. Pitman, M. Sheridan, M. Bursik, B. Rupp, A. Webber, A. Stinton, L. Namikawa, and C. Renschler (2005). "Parallel adaptive numerical simulation of dry avalanches over natural terrain". Journal of Volcanology and Geothermal Research 139 (1-2), pp. 1-21. DOI: $10.1016 / \mathrm{j}$. jvolgeores.2004.06.014.

Piedrahita, D. A., C. Aguilar-Casallas, E. ArangoPalacio, H. Murcia, and J. Gómez-Arango (2018). "Estratigrafía del cráter y morfología del volcán Cerro Machín, Colombia". Boletín de Geología 40 (3), pp. 29-48. ISSN: 2145-8553. Dor: 10.18273/revbol. v40n3-2018002.

Pierson, T. C., R. J. Janda, J.-C. Thouret, and C. A. Borrero (1990). "Perturbation and melting of snow and ice by the 13 November 1985 eruption of Nevado del Ruiz, Colombia, and consequent mobilization, flow and deposition of lahars". Journal of Volcanology and Geothermal Research 41 (1-4), pp. 17-66. DoI: 10 . 1016/0377-0273(90) 90082-q.

Pulgarín, B., C. Cardona, A. Agudelo, C. Santacoloma, M. L. Monsalve, M. Calvache, C. Murcia, M. Cuéllar, E. Medina, R. Balanta, Y. Calderón, Ó. Leiva, M. Ordóñez, and D. Ibáñez (2015). "Erupciones recientes del Volcán Nevado del Huila: Lahares asocia- dos y cambios morfológicos del glaciar". Boletín Geológico (43), pp. 75-87. Dor: 10.32685 / 0120-1425/ boletingeo.43.2015.21.

Richardson, J. and L. J. Connor (2014). Lava C Version 0.1. URL: https://vhub.org/resources/3597 (visited on $10 / 31 / 2020)$.

Schilling, S. P. (1998). "Laharz: GIS tools for automated mapping of lahar-inundation hazard zones" (US Geological Survey Open-File Report 98-638).

- (2014). "Laharz_py: GIS tools for automated mapping of lahar inundation hazard zones" (US Geological Survey Open-File Report 2014-1073). Dor: 10 . 3133/ofr20141073.

Schwaiger, H. F., R. P. Denlinger, and L. G. Mastin (2012). "Ash3d: A finite-volume, conservative numerical model for ash transport and tephra deposition". Journal of Geophysical Research: Solid Earth 117 (B4). DOI: $10.1029 / 2011$ jb008968.

Servicio Geológico Colombiano (2015). Actualización del mapa de amenaza volcánica del Volcán Galeras. Tech. rep. Servicio Geológico Colombiano.

Sheridan, M. F. and T. Kover (1996). "FLOW3D: A computer code for simulating rapid, open channel volcanic flows". Proc. UJST workshop on the Technology of Disaster Prevention against Local Severe Storms, pp. 155-163.

Sheridan, M. F. and J. L. Macías (1992). "PC software for 2-dimensional gravity-driven flows: Application to Colima and El Chichón Volcanoes, México". Proceedings of the Second International Meeting on Volcanology, p. 5. 